\title{
Association between religiosity and happiness in patients with chronic kidney disease on hemodialysis
}

\author{
Associação entre religiosidade e felicidade em pacientes com doença \\ renal crônica em hemodiálise
}

\section{Authors}

Janaína Siqueira ${ }^{1}$ iD

Natália Maria Fernandes ${ }^{1}$ iD

Alexander Moreira-Almeida ${ }^{1}$ iD

${ }^{1}$ Universidade Federal de Juiz de Fora, Faculdade de Medicina, NUPES - Núcleo de Pesquisas em Espiritualidade e Saúde, Juiz de Fora, MG, Brasil.
Submitted on: 04/24/2018. Approved on: 08/15/2018.

\section{Correspondence to:}

Janaína Siqueira.

E-mail: janainasiqueirar@gmail.com

DOI: 10.1590/2175-8239-JBN-2018-0096

\section{Abstract}

Objectives: Religiosity/spirituality (R/S) seems to be a relevant factor in chronic diseases adaptation, but there is a lack of studies involving chronic kidney disease (CKD). This study aimed to investigate the association between R/S and happiness among CKD patients on hemodialysis and whether Sense of Coherence (SC) mediates this possible association. Methods: This was a cross-sectional study in two renal replacement therapy centers in Brazil, involving 161 adults on hemodialysis. Linear regressions were performed to evaluate the association between R/S (predicting variable measured with Duke Religious Index - DUREL) and happiness (outcome variable), adjusted for sociodemographic, clinical, and some laboratory variables. Later, SC was added to the model to test the possible mediating effect. Results: Most patients $(91.20 \%)$ reported some religious affiliation. Private Religiosity (PR) $(\beta$ $=0.53 ; 95 \% \mathrm{CI}=0.01$ a 1.06$)$, Intrinsic Religiosity (IR) $(\beta=0.48 ; 95 \% \mathrm{CI}=$ 0.18 a 0.79$)$, and SC $(\beta=0.11 ; 95 \% \mathrm{CI}=$ -0.09 a 0.15 ) correlated with higher levels of happiness, controlling for clinical and sociodemographic variables. When SC was included in the model, IR $(\beta=$ $0.34 ; 95 \% \mathrm{CI}=0.07$ to 0.60$)$ and $\mathrm{SC}(\beta$ $=0.11 ; 95 \% \mathrm{CI}=0.08$ to 0.14$)$ remained significantly. No clinical or sociodemographic variable correlated with happiness. Conclusions: Patients on hemodialysis showed high levels of R/S, which correlated with higher happiness levels. Clinical and sociodemographic variables were not correlated with patients' happiness. Psychosocial variables such as $\mathrm{R} / \mathrm{S}$ and SC are potential key targets for interventions to promote better survival quality among CKD patients.

\section{Resumo}

Objetivos: Religiosidade/espiritualidade (R/E) parecem ser fatores relevantes na adaptação a doenças crônicas, mas faltam estudos nessa área envolvendo pacientes com doença renal crônica (DRC). O presente estudo teve como objetivo investigar a associação entre R/E e felicidade em pacientes com DRC em hemodiálise e se o senso de coerência (SC) faz a mediação dessa possível associação. Métodos: Estudo transversal realizado em dois centros de terapia renal substitutiva no Brasil com 161 adultos em hemodiálise. Regressões lineares foram utilizadas para avaliar a associação entre R/E (variável preditora medida pelo Índice de Religiosidade de Duke - DUREL) e felicidade (variável de desfecho), ajustadas para variáveis sociodemográficas, clínicas e algumas variáveis laboratoriais. Posteriormente, o SC foi acrescentado ao modelo para testar seu possível efeito mediador. Resultados: A maioria dos pacientes $(91,20 \%)$ relatou alguma afiliação religiosa. Religiosidade Privada $(\mathrm{RP})(\beta=0,53$; IC $95 \%=0,01$ a 1,06$)$ e Religiosidade Intrínseca (RI) $(\beta=0,48$; IC 95\% = $0,18$ a 0,79$)$ e SC $(\beta=0,11$; IC $95 \%=-0,09$ a 0,15$)$ foram correlacionadas a níveis mais elevados de felicidade após controle para variáveis clínicas e sociodemográficas. Quando SC foi incluído no modelo, IR ( $\beta=0.34 ; 95 \%$ $\mathrm{IC}=0.07 \mathrm{a} 0.60)$ and $\mathrm{SC}(\beta=0.11 ; 95 \% \mathrm{IC}=$ 0.08 a 0.14 ) continuaram se correlacionando significativamente com felicidade. Nenhuma variável clínica ou sociodemográfica apresentou correlação com felicidade. Conclusões: Os pacientes em hemodiálise apresentaram altos níveis de R/E, que por sua vez foi correlacionada com elevados níveis de felicidade. As variáveis clínicas e sociodemográficas não exibiram correlação com a felicidade dos pacientes. Variáveis psicossociais como R/E e SC são possíveis alvos para intervenções destinadas a promover a melhora da qualidade de sobrevida dos pacientes com DRC. 
Keywords: Renal Insufficiency, Chronic; Kidney Failure, Chronic; Renal Dialysis; Religion; Spirituality; Quality of Life.
Palavras-chave: Insuficiência Renal Crônica; Falência Renal Crônica; Diálise Renal; Religião; Espiritualidade; Qualidade de Vida.

\section{INTRODUCTION}

Chronic kidney disease (CKD) is a health problem of increasing importance. The overall prevalence of CKD in the general US population was 2,067 patients per million in $2014^{1}$ and the prevalence in Latin America was 660 patients per million in $2010^{2}$.

For category 5 of $\mathrm{CKD}$, requiring renal replacement therapy, only a successful renal transplant can offer renal function close to normal. The treatment process is often a difficult experience ${ }^{3}$ and the most frequent psychological conditions found in these patients are anxiety, stress, and depression ${ }^{4}$. There is also a decrease in quality of life $(\mathrm{QoL})^{3}$.

We adopted a concept proposed by Lyubomirsky, in which happiness is the sum of two parts: positive emotions and the perception that life has meaning ${ }^{5,6}$. Happy people tend to be more successful in various domains of life, ${ }^{7,8}$ but identifying the factors that generate happiness remains a challenge.

A growing number of studies report that higher levels of religious involvement tend to be associated with happiness, better well-being and physical health, lower rates of depression, suicide, substance use/abuse and overall mortality, ${ }^{9,10}$ and improved adaptation to chronic diseases ${ }^{11}$. Religiosity/Spirituality $(\mathrm{R} / \mathrm{S})$ was also considered a relevant factor of QoL in patients with $\mathrm{CKD}^{12,13,14}$.

Spirituality is the relationship with the sacred and the transcendent, which may or may not lead to the development of a religion. Religiosity is defined as the involvement (believing, following and/or practicing) of the individual with a religion ${ }^{10}$. Understanding the mechanisms that mediate the association between $\mathrm{R} / \mathrm{S}$ and health has been a major challenge ${ }^{10,15}$. The most cited mechanisms include social support, healthy behaviors, religious practices, coping strategies, and cognitive framework ${ }^{9,16}$. However, these mediators have generated inconsistent results ${ }^{17,18,19}$.

Sense of coherence is derived from the salutogenic theory, which investigates the factors that allow the maintenance of health, and is divided into three components: 1) Comprehensibility: perception that external or internal stimuli are structured, predictable, and explicable 2) Manageability: perception that the resources to cope with the needs posed by these stimuli are available, and 3) Meaningfulness: perception that these needs are challenges in which it is worth investing and engaging ${ }^{20}$. Studies have shown a positive association between sense of coherence and QoL and inverse associations with indicators of physical and mental illness in several populations ${ }^{19,21}$.

To test this hypothesis, the objective of the present study was to investigate the association between $\mathrm{R} / \mathrm{S}$ levels and happiness in patients with CKD who were on hemodialysis and to determine whether this possible association is fully or partially mediated by sense of coherence.

\section{Methods}

\section{PARTICIPANTS AND STUDY SETTING}

A cross-sectional study was conducted involving outpatients from two renal replacement therapy centers in the city of Juiz de Fora, Minas Gerais, Brazil: the University Hospital of the Federal University of Juiz de Fora (HU-UFJF) and NEFROCLIN. Inclusion criteria were adults ( $\geq 18$ years of age), with $\geq 1$ year on dialysis, at which point patients are more adapted to therapy. Patients with cognitive deficits that prevented them from answering the questionnaires were excluded.

From the list of patients provided by HU-UFJF, 64 patients were identified; 15 refused to participate, 16 did not meet the inclusion criteria, and 3 were not located, for a total of 30 study participants. Of the 207 patients identified at NEFROCLIN, 14 refused to participate, 35 did not meet the inclusion criteria, 15 had died, 8 had received a transplant, 1 had renal function recovery, and 3 were lost to follow-up, for a total of 131 patients participating in the study. Thus, the final sample contained 161 participants. All participants signed an informed consent form to participate in the study. The study was approved by the Research Ethics Committee of the HU-UFJF, under protocol 375/2011, as well as the Ethics Committees of each treatment center. Data were collected between July 2012 and March 2013.

Self-reporting questionnaires were administered face-to-face by psychology students trained for this 
study. Throughout the data collection process, regular meetings were held to standardize the study and avoid divergences. Data were collected during hemodialysis sessions at the respective centers, and questionnaires were always administered after the patients had received a snack and were therefore more alert.

\section{Measures}

Socio-demographic data obtained through interviews included age, race/skin color, sex, educational level, marital status, employment status, family income, and religious denomination. Clinical and laboratory data obtained from medical records included hemoglobin, parathyroid hormone (PTHi), KtV (dialysis adequacy index), comorbidities, and time on dialysis. If no data was available for the month in which the survey was applied, data from the month closest to the interview were used.

Religiosity: a validated Portuguese version of the Duke Religious Index (DUREL) ${ }^{22,23}$ was used. The DUREL has five items, is self-applicable, and indicates the level of religious involvement by addressing three dimensions of religiosity commonly related to health: Organizational Religiosity (OR), Private Religiosity (PR), and Intrinsic Religiosity (IR). All answers are on a Likert scale.

Sense of Coherence: a validated Portuguese version of Antonovsky's Life Orientation Questionnaire/ Sense of Coherence Scale ${ }^{24,25}$ was used. The tool evaluates three dimensions: 1) Comprehensibility, 2) Manageability, and 3) Meaningfulness. Higher scores indicate a stronger sense of coherence with a possible range of 29 to 203.

Happiness: a validated Portuguese version of the Subjective Happiness Scale (SHS) ${ }^{26}$ was used, which is self-applicable and includes 4 items answered on a Likert scale. Higher scores indicate greater happiness, with a possible range of 4 to 28 points.

\section{STATISTICAL ANALYSIS}

A descriptive analysis of the data was performed, and data are shown as the mean \pm standard deviation or frequency, depending on the characteristics of the variable. We performed a linear regression with happiness as the outcome variable, and adjusted the model for sociodemographic, clinical, and laboratory variables (Model 1). Then, we added each of the religiosity dimensions to the other models, adding Organizational Religiosity to model 2, Private
Religiosity to model 3, Intrinsic Religiosity to model 4 and sense of coherence to model 5. Given the association of Private Religiosity, Intrinsic Religiosity, and sense of coherence variables with happiness, two additional models were fitted, the first using Private Religiosity and sense of coherence as predictor variables and the second using Intrinsic Religiosity and sense of coherence, with happiness as the outcome. These models were adjusted for sociodemographic, clinical, and laboratory variables.

The data were analyzed using SPSS (Statistical Package for the Social Sciences) 20.0 for Windows. A $95 \%$ confidence interval was adopted.

\section{Results}

The sample consisted predominantly of middle-aged adults $(57.8 \%$ were between 41 and 64 years old), with low educational level $(60.9 \%$ had less than a high school education), and unemployed (61.5\% retired and $26.7 \%$ on medical leave). There was an almost equitable division between men and women and between white, black, and mixed-race individuals, indicating data similar to those of the Brazilian Dialysis Census ${ }^{27}$. The majority of the population was Catholic $(59.6 \%)$, followed by Protestant $(18.6 \%)$, and other affiliations $(13 \%)$. No religious affiliation was reported by $8.7 \%$ of the sample (Table 1 ).

In Table 2, we show the positive association between happiness, sense of coherence, Private Religiosity and Intrinsic Religiosity. It is interesting to note that the greater the religiosity, the greater the happiness - the highest coefficients were for Private Religiosity (beta: 0.53 ) and Intrinsic Religiosity (beta: 0.48). No association was found between organizational religiosity and happiness.

Table 3 shows that, although the sense of coherence had a lower B (beta) coefficient, when evaluated separately with Private Religiosity and IR, it interfered with the coefficients of the variables (see table 2). The betas decreased for Private Religiosity (0.53-0.42) and Intrinsic Religiosity (0.48-0.34), and the association of Private Religiosity and happiness lost significance. The association between Intrinsic Religiosity and happiness remained significant.

\section{Discussion}

Our study indicated that R/S is associated with higher levels of happiness and that sense of coherence is an important associated factor of this relationship. The 
Table 1 Demographic characteristics, Religiosity, Sense of COHERENCE, AND hapPiness $(\mathrm{N}=161)$

\begin{tabular}{|c|c|c|c|}
\hline Characteristics & & $\mathrm{N}$ & $\%$ \\
\hline \multirow[t]{3}{*}{ Age group } & Up to 40 years & 20 & 12.4 \\
\hline & 41 to 64 years & 93 & 57.8 \\
\hline & 65 years and over & 48 & 29.8 \\
\hline \multirow[t]{4}{*}{ Race } & White & 54 & 33.5 \\
\hline & Black & 56 & 34.8 \\
\hline & Brown & 45 & 28.0 \\
\hline & Other & 6 & 3.7 \\
\hline Gender & Male & 87 & 54.0 \\
\hline \multirow[t]{4}{*}{ Educational level } & None & 16 & 9.9 \\
\hline & Up to elementary school & 98 & 60.9 \\
\hline & Up to high school & 32 & 19.9 \\
\hline & College & 15 & 9.3 \\
\hline \multirow[t]{3}{*}{ Marital status } & Not married & 39 & 24.2 \\
\hline & Married/Living together & 84 & 52.2 \\
\hline & Widowed/Divorced/Separated & 38 & 23.6 \\
\hline \multirow[t]{7}{*}{ What is your current working situation } & Full-Time Employee & 1 & 0.6 \\
\hline & Employed part-time & 4 & 2.5 \\
\hline & Unemployed & 2 & 1.2 \\
\hline & Retired & 99 & 61.5 \\
\hline & Away/Leave or Sickness & 43 & 26.7 \\
\hline & Student & 1 & 0.6 \\
\hline & Others & 11 & 6.8 \\
\hline \multirow[t]{2}{*}{ Income bracket } & $1 \mathrm{MW}$ or less & 102 & 63.4 \\
\hline & 1.1 to $2 \mathrm{MW}$ & 59 & 36.6 \\
\hline \multirow[t]{4}{*}{ Comorbidity } & None & 29 & 18.7 \\
\hline & 1 & 79 & 51 \\
\hline & 2 & 32 & 20.6 \\
\hline & 3 & 15 & 9.7 \\
\hline Diabetes & Yes & 44 & 27.3 \\
\hline \multirow[t]{5}{*}{ Religious affiliation } & Catholic & 96 & 59.6 \\
\hline & Evangelical & 30 & 18.6 \\
\hline & Others & 21 & 13.0 \\
\hline & None & 14 & 8.7 \\
\hline & & Mean & SD \\
\hline $\mathrm{Hb}(\mathrm{g} / \mathrm{dL})$ & & 11.0 & 1.9 \\
\hline PTHi (pg/mL) & & 517 & 413 \\
\hline $\mathrm{Kt} / \mathrm{N}$ & & 1.45 & 0.40 \\
\hline Religiosity & Organizational (1a 6) & 4.1 & 1.7 \\
\hline \multirow[t]{2}{*}{$(\min -\max )$} & Private (1 a 6) & 4.3 & 1.7 \\
\hline & Intrinsic (3 a 15) & 12.9 & 2.9 \\
\hline Sense of coherence(min - max) & - & 137.2 & 23.8 \\
\hline Happiness & - & 19.7 & 5.0 \\
\hline
\end{tabular}




\begin{tabular}{lcccc} 
TABLE 2 & \multicolumn{2}{l}{ LINEAR REGRESSION BETWEEN RELIGIOSITY AND SENSE OF COHERENCE WITH HAPPINESS (ADJUSTED FOR CLINICAL } \\
& AND LABORATORY VARIABLES) \\
\hline & Variable & BETA Coefficient & 95\% Confidence Interval & $p$ \\
\hline Model 1 & Organizational religiosity & 0.42 & -0.11 to 0.95 & 0.11 \\
Model 2 & Private religiosity & $\mathbf{0 . 5 3}$ & 0.01 to 1.06 & $\mathbf{0 . 0 4}$ \\
Model 3 & Intrinsic religiosity & $\mathbf{0 . 4 8}$ & 0.18 to 0.79 & $\mathbf{0 . 0 0 2}$ \\
Model 4 & Sense of coherence & $\mathbf{0 . 1 1}$ & 0.09 to 0.15 & $\mathbf{0 . 0 0 0 1}$ \\
\hline
\end{tabular}

Adjusted for: age, gender, education, comorbidity, dialysis time (years) and hemoglobin (g/dL), Kt/N (adequacy index in dialysis), and PTH (parathyroid hormone-pg/mL) Statistically significant results $(p<0.05)$ are in bold.

\begin{tabular}{|c|c|c|c|c|}
\hline \multirow{2}{*}{$\begin{array}{l}\text { TABLE } 3 \\
\text { Variabl }\end{array}$} & \multicolumn{4}{|c|}{$\begin{array}{l}\text { AsSOCIATION BETWEEN RELIGIOSITY AND SENSE OF COHERENCE WITH HAPPINESS (ADJUSTED FOR } \\
\text { SOCIODEMOGRAPHIC AND CLINICAL VARIABLES) }\end{array}$} \\
\hline & & BETA Coefficients & Confidence Interval & $p$ \\
\hline \multicolumn{2}{|c|}{ Sense of coherence } & 0.11 & -0.09 to 0.15 & $<0.0001$ \\
\hline \multicolumn{2}{|c|}{ Private Religiosity } & 0.42 & -0.03 to 0.88 & 0.06 \\
\hline \multicolumn{2}{|c|}{ Sense of coherence } & 0.11 & 0.08 to 0.14 & $<0.0001$ \\
\hline \multicolumn{2}{|c|}{ Intrinsic Religiosity } & 0.34 & 0.07 to 0.60 & 0.01 \\
\hline
\end{tabular}

clinical and sociodemographic variables examined were not correlated with happiness.

To our knowledge, this is the first study to investigate levels of happiness and sense of coherence among patients with CKD, as well as to investigate the possible mediating role of sense of coherence and the impact of R/S on health and happiness indicators. Thus, to compare our data with the literature, we used studies with samples that are related (e.g., patients with other chronic diseases) or have related outcomes (e.g., QoL or mental disorders) but not necessarily the same as in the present study.

In sociodemographic terms, our sample is similar to the population of patients on hemodialysis ${ }^{27}$. It is worth noting the high degree of functional/work limitation in the sample, as $88.2 \%$ were retired or on work leave, although $70.2 \%$ were under 65 years old. The distribution of religious affiliation is close to that of the Brazilian population ${ }^{28}$, which is mostly Catholic, followed by evangelical Christian. The sample had high levels of religious involvement on all three measured dimensions: intrinsic, private, and organizational, corroborating results from other similar samples ${ }^{11}$.

In this study, we found that sense of coherence, Private Religiosity, and Intrinsic Religiosity were consistently correlated with levels of happiness. R/S is generally recognized as a potential coping strategy for addressing the challenges of CKD. Several studies have found that, in patients with $\mathrm{CKD}, \mathrm{R} / \mathrm{S}$ is associated with a decreased perception of the disease negative impact, decreased depression, increased search for social support, and increased QoL and satisfaction ${ }^{13,14,29,30}$. Evidence from the literature also indicates a usually positive association between levels of religious involvement and levels of positive aspects such as well-being, optimism, and happiness ${ }^{31}$.

Although Organizational Religiosity is usually associated with lower levels of depression and better health, in the present study, it was the only dimension of religiosity that had no association with happiness. A possible explanation is that in situations of greater physical limitation, patients have greater difficulty attending religious meetings and emphasize personal and private religiosity.

An interesting finding was the non-correlation of clinical and laboratory variables with happiness. To our knowledge, this was the first time this association was investigated in patients with CKD. Objective clinical variables often have a much weaker relationship than assumed with subjective assessments of the patient's health status and level of well-being. However, the reasons for this effect are still unclear. Age is associated with worse QoL in studies of patients with $\mathrm{CKD}^{32,33}$. The laboratory variable that correlates most frequently with QoL is the serum hemoglobin level ${ }^{34}$.

Although $\mathrm{R} / \mathrm{S}$ is usually associated with indicators of health and well-being, the mechanisms that mediate this association is a current knowledge gap ${ }^{15,35}$. 
We hypothesized that sense of coherence would be a possible mediator of the relationship between $\mathrm{R} / \mathrm{S}$ and happiness. Our findings confirmed our hypothesis, showing a consistent association between R/S and sense of coherence $(0.09$ to $0.15, p<0.0001)$. It seems that sense of coherence acts as a full mediator on the impact of Organizational Religiosity (sense of coherence beta: 0.11 (-0.09 to 0.15$), p<0.0001$ and Private Religiosity beta: 0.42 (0.03 a 0.88$), p=0.06$ ) and as a partial mediator on the impact of Intrinsic Religiosity on the levels of happiness in hemodialysis patients (sense of coherence beta: 0.11 (0.08 to 0.14 ), $p<0.0001$ and Intrinsic Religiosity beta: 0.34 (0.07 to 0.60$), p=0.01$ ).

Other studies have also found a positive association between $\mathrm{R} / \mathrm{S}$ and sense of coherence ${ }^{36,37}$. A review showed the effectiveness of religious/spiritual interventions designed to increase participants' sense of coherence $^{38}$.

The present data suggest that R/S and sense of coherence may be targets of psychosocial interventions, such as psychoeducational programs and psychotherapy, that aim to address outcomes in $\mathrm{CKD}^{7,39}$.

Identifying and supporting religious coping strategies and fostering the use of spiritual resources to allow patients to cope better with CKD may be effective strategies.

There is evidence that the simple collection of a patient's spiritual history, even if over a short duration (2-5 minutes), is associated with greater treatment satisfaction and better QoL ${ }^{[40,41]}$. Taking the spiritual history has been recognized as a relatively simple practical way of integrating spirituality into patient care ${ }^{42}$.

The present study has limitations. Because it is a cross-sectional study, causal inferences about the effect of R/S on sense of coherence and happiness should be made with caution. Because our findings are novel, it is important that other researchers attempt to replicate them in longitudinal studies. Care should be taken in generalizing these results to other contexts. This study was conducted in Brazil, where the population is highly religious ${ }^{28}$. However, the clinical and sociodemographic profile of our sample is similar to that of studies conducted in other countries as well as in Brazil, and the impacts of R/S on health have been replicated across a wide range of sociocultural and geographic settings ${ }^{34,43}$. Another limitation is the absence of data on central nervous system drugs, which was due to difficulty in accessing this information in the medical record.

The strengths of this study include its originality, relatively large sample, use of well-established measures, and broad clinical implications.

\section{Conclusion}

In summary, the present study found for the first time that R/S and sense of coherence are related to the happiness of patients on hemodialysis. No sociodemographic, clinical, or laboratory variables were associated with patients' levels of happiness. In view of the increasing value and attention given to the well-being and QoL of patients with CKD, R/S should be better investigated as possible components of psychosocial interventions that, together with drug and renal replacement therapies, may promote better QoL.

\section{References}

1. United States Renal Data System [Internet]. 2016 ADR Chapters [cited $2017 \mathrm{Jul}$ 17]. Available from: https://www.usrds. org/2016/view/Default.aspx

2. Pecoits-Filho R, Rosa-Diez G, Gonzalez-Bedat M, Marinovich S, Fernandez S, Lugon J, et al. Tratamento substitutivo da função renal na doença renal crônica: uma atualização do Registro Latino Americano de Diálise e Transplante. J Bras Nefrol 2015;37:9-13.

3. Bragazzi NL, Puente GD. Chronic Kidney Disease, Spirituality and Religiosity: A Systematic Overview with the List of Eligible Studies. Health Psychol 2013;1:e26.

4. Stumm EMF, Abreu PB, Ubessi LD, Barbosa DA. Estressores e atenuantes de estresse entre idosos em tratamento hemodialítico. Rev Ciênc Saúde 2013;6:2-11.

5. Lyubomirsky S. The Myths of Happiness: What Should Make You Happy, but Doesn't, What Shouldn't Make You Happy, but Does. New York: Penguin Press; 2013.

6. Cloninger CR. The science of well-being: an integrated approach to mental health and its disorders. World Psychiatry 2006;5:71-6.

7. Seligman MEP. Authentic Happiness: Using the New Positive Psychology to Realize Your Potential for Lasting Fulfillment. New York: Free Press; 2002.

8. Lyubomirsky S, King L, Diener E. The benefits of frequent positive affect: does happiness lead to success? Psychol Bull 2005; 131:803-55

9. Moreira-Almeida A, Lotufo Neto F, Koenig HG. Religiousness and mental health: a review. Rev Bras Psiquiatr 2006;28:24250.

10. Koenig H, King D, Carson VB. Handbook of Religion and Health. 2nd ed. New York: Oxford University Press; 2012.

11. Lucchetti G, Almeida LGC, Granero AL. Espiritualidade no paciente em diálise: o nefrologista deve abordar? J Bras Nefrol 2010;32:128-32.

12. Finkelstein SH, West W, Gobin J, Finkelstein SH, Wuerth D. Spirituality, quality of life and the dialysis patient. Nephrol Dial Transplant 2007;22:2432-4.

13. Kimmel PL, Emont SL, Newmann JM, Danko H, Moss AH. ESRD patient quality of life: symptoms, spiritual beliefs, psychosocial factors. Am J Kidney Dis 2003;42:713-21.

14. Lucchetti G, de Almeida LGC, Lucchetti ALG. Religiousness, mental health, and quality of life in Brazilian dialysis patients. Hemodial Int 2012;16:89-94. 
15. Moreira-Almeida A. Religion and health: the more we know the more we need to know. World Psychiatry 2013;12:37-8.

16. Koenig HG, McCullough M, Larson DB. Handbook of Religion and Health: A Century of Research Reviewed. New York: Oxford University Press; 2001.

17. Corrêa AAM, Moreira-Almeida A, Menezes PR, Vallada H, Scazufca M. Investigating the role played by social support in the association between religiosity and mental health in low income older adults: results from the São Paulo Ageing \& Health Study (SPAH). Rev Bras Psiquiatr 2011;33:157-64.

18. George LK, Ellison CGC, Larson DB. Explaining the relationships between religious involvement and health. Psychol Inq 2002;13:190-200.

19. Mittelmark, MB, Sagy S, Eriksson M, Bauer G, Pelikan JM, Lindström B, et al. The Handbook of Salutogenisis. New York: Springer; 2017.

20. Eriksson M, Lindström B. Antonovsky's sense of coherence scale and the relation with health: a systematic review. J Epidemiol Community Health 2006;60:376-81.

21. Eriksson M, Lindström B. Antonovsky's sense of coherence scale and its relation with quality of life: a systematic review. J Epidemiol Community Health 2007;61:938-44.

22. Moreira-Almeida A, Peres MF, Aloe F, Lotufo Neto F, Koenig HG. Portuguese version of Duke Religious Index: DUREL. Rev Psiquiatr Clín 2008;35:31-2.

23. Lucchetti G, Granero Lucchetti AL, Peres MF, Leão FC, Moreira-Almeida A, Koenig HG. Validation of the Duke Religion Index: DUREL (Portuguese Version). J Relig Health 2012;51:579-86.

24. Antonovsky A. Unraveling the Mystery of Health: How People Manage Stress and Stay Well. San Francisco: Jossey-Bass; 1987.

25. Dantas RAS. Adaptação cultural e validação do Questionário de Senso de Coerência de Antonovsky em uma amostra de pacientes cardíacos brasileiros [Free Teaching Thesis]. Ribeirão Preto: Escola de Enfermagem de Ribeirão Preto, USP; 2007.

26. Damásio BF, Zanon C, Koller SH. Validation and Psychometric Properties of the Brazilian Version of the Subjective Happiness Scale. Universitas Psychol 2014;13:17-24.

27. Sesso RC, Lopes AA, Thomé FA, Lugon JR, Martins CT. Inquérito Brasileiro de Diálise Crônica 2014. J Bras Nefrol 2016;38:54-61.

28. Moreira-Almeida A, Pinsky I, Zaleski M, Laranjeira R. Envolvimento religioso e fatores sociodemográficos: resultados de um levantamento nacional no Brasil. Rev Psiquiatr Clín 2010;37:12-5.

29. Wechpradit J, Thaiyuenwong J, Kanjanabuch T. Health promotion behaviors and related factors in end stage renal disease patients treated with continuous ambulatory peritoneal dialysis. J Med Assoc Thai 2011;94:S113-8.
30. Davison SN, Jhangri GS. The relationship between spirituality, psychosocial adjustment to illness, and health-related quality of life in patients with advanced chronic kidney disease. J Pain Symptom Manage 2013;45:170-8.

31. Sahraian AI, Gholami A, Javadpour A, Omidvar B. Association between religiosity and happiness among a group of Muslim undergraduate students. J Relig Health 2013;52:450-3.

32. Grincenkov FRS, Fernandes N, Chaoubah A, Bastos K, Qureshi AR, Pécoits-Filho R, et al. Fatores associados à qualidade de vida de pacientes incidentes em diálise peritoneal no Brasil (BRAZPD). J Bras Nefrol 2011;33:38-44.

33. Franco MR, Fernandes NM. Dialysis in the elderly patient: a challenge of the XXI century--narrative review. J Bras Nefrol 2013;35:132-41. Erratum in J Bras Nefrol 2013;35:244.

34. Pereira BDS, Fernandes NDS, Melo NP, Abrita R, Grincenkov FRDS, Fernandes NMDS. Beyond quality of life: a cross sectional study on the mental health of patients with chronic kidney disease undergoing dialysis and their caregivers. Health Qual Life Outcomes 2017;15:74.

35. Hill PC, Pargament KI. Advances in the conceptualization and measurement of religion and spirituality: implications for physical and mental health research. Am Psychol 2003;58:64-74.

36. Conway-Phillips R, Janusek L. Influence of sense of coherence, spirituality, social support and health perception on breast cancer screening motivation and behaviors in African American women. ABNF J 2014;25:72-9.

37. Cowlishaw S, Niele S, Teshuva K, Browning C, Kendig H. Older adults' spirituality and life satisfaction: A longitudinal test of social support and sense of coherence as mediating mechanisms. Ageing Soc 2013;33:1243-62.

38. Jeserich F. Can Sense of Coherence Be Modified by Religious/ Spiritual Interventions? A Critical Appraisal of Previous Research. Interdiscip J Res Relig 2013;9.

39. Walker, ER, McGee RE, Druss BG. Mortality in mental disorders and global disease burden implications: a systematic review and meta-analysis. JAMA Psychiatry 2015;72:334-41.

40. Kristeller JL, Rhodes M, Cripe LD, Sheets V. Oncologist Assisted Spiritual Intervention Study (OASIS): patient acceptability and initial evidence of effects. Int J Psychiatry Med 2005;35:329-47.

41. Williams JA, Meltzer D, Arora V, Chung G, Curlin FA. Attention to inpatients' religious and spiritual concerns: predictors and association with patient satisfaction. J Gen Intern Med 2011;26:1265-71.

42. Moreira-Almeida A, Koenig HG, Lucchetti G. Clinical implications of spirituality to mental health: review of evidence and practical guidelines. Rev Bras Psiquiatr 2014;36:176-82.

43. Saffari ML, Pakpour AH, Naderi MK, Koenig HG, Baldacchino DR, Piper CN. Spiritual coping, religiosity and quality of life: a study on Muslim patients undergoing haemodialysis. Nephrology (Carlton) 2013;18:269-75. 